\title{
対話破綻検出の対話システムへの適用 \\ Applying Dialogue Breakdown Detection to Dialogue Systems
}

\author{
稻葉 通将 \\ 広島市立大学大学院情報科学研究科 \\ Graduate School of Information Sciences, Hiroshima City University \\ ianba@hiroshima-cu.ac.jp \\ 高橋 健一（同上) \\ Kenichi Takahashi takahasi@hiroshima-cu.ac.jp
}

keywords: dialogue breakdown detection, dialogue system, chat-oriented

\begin{abstract}
Summary
Dialogue breakdown detection is a technique used for identifying inappropriate utterances in dialogue systems. Although it is generally assumed that dialogue breakdown detection avoids generating system responses that then cause difficulties in continuing the given dialogue, this has yet to be verified. In this paper, we apply the dialogue breakdown detection technique to generate responses for a chat-oriented dialogue system and experimentally verify that performance is improved by measuring the extent to which dialogue breakdown is avoided. Our experimental results show that naturalness of dialogue and user satisfaction level are improved but enjoyment of dialogue is deteriorated when using this technique.
\end{abstract}

1. は じめに

人と日常会話や杂隹談を行う非タスク指向型対話システム は , エンターテイメントの用途だけではなく , コンピュー タ・ロボットの社会性獲得のための技術として活発に研 究が進められている．また, Amazon.comによる Alexa Prize*1やNIPS 2018 において Conversational Intelligence Challenge (ConvAI) ${ }^{* 2}$ が開催されるなど , 非タスク指向 型対話システムに関する競技会も次々と企画・開催され ている。

対話破綻検出は人とシステムの対話において , システム の不適切な発話を発見する技術であり,特に非タスク指向 型対話システムを対象とした研究が行われている. 谷の競 技会である対話破綻検出チャレンジ (Dialogue Breakdown Detection Challenge: DBDC) も2015 年から毎年開催さ れている [東中 15, 東中 16, Higashinaka 17]. 対話破綻 検出により, システムが自分の発話をする前に, 享の発 話が対話破綻につながることがわかり，対話破綻を事前 に回避することが可能となるとされている [東中 15] . し かし，実際に乥れを検証した例は存在しない．また，光 の技術を具体的にどのように適用すればより効果的に破 綻を回避できるかということも明らかではない．

そこで本論文では, 非タスク指向型対話システムの出 力した応答候補に対し対話破綻検出を適用し，対話破綻 を回避することで応答性能の向上が可能であるかを検証

*1 https://developer.amazon.com/alexaprize

$* 2$ http://convai.io/
する . 㚇のために, 破綻検出の適用手法を複数提案し, ど のような適用手法が有効であるかの実験も行う .

\section{2. 関 連 研 究}

対話破綻検出を対話システムの応答選択に適用した研 究は少数であるが存在する.Sugiyama は対話破綻検出 を用例ベースの非タスク指向型対話システムに応用する 手法を提案している [Sugiyama 16] . 本手法では , まず Word2Vec を用いて入力発話と類似した発話をデータベー スから検索し，上位 20 件の応答候補を得る。次に，対話 破綻検出手法により出力された破綻確率により応答候補 をリランキングし，1 位の応答候補を出力するというも のである・また, Mori らは複数の応答生成モジュールが 生成した応答候補から，応答候補を選択する基準の 1 つ として対話破綻確率を用いたシステムを提案した [Mori 16].しかし，これらの研究では, 対話破綻検出を使用し ない場合の評価は行っておらず，また，どのように適用 すればより性能が向上するかという評価も行っていない．

対話破綻検出に関連する研究としては, WOCHAT*3 に よる取り組みが挙げられる．WOCHAT では非タスク指 向型対話システムとユーザの対話データに対し，DBDC で使用されている破綻ラベルと類似した 3 種類のラベル (invalid, acceptable, valid) を用いたアノテーションとデー タの公開が進められている [Charras 16, Curry 16] .この データは本研究で用いるDBDC のデータと共通点が多い

\footnotetext{
*3 http://workshop.colips.org/wochat/
} 
ことから，本研究の成果はこのデータを用いた研究にも 応用可能であると考えられる。

\section{3. 対話システム}

本研究では, 対話破綻検出を対話システムに適用した 際の応答性能の変化を分析するため, システムは入力に 対し, 複数の応答候補が出力できるものを用いる.これ は, ELIZA [Weizenbaum 66] や ALICE [Wallace 08] の ような，入力に対する応答が固定されているようなルー ルベースの対話システムでは，応答が破綻と判定された 際に別の応答ができず, 性能の変化の分析が困難なため である . 複数の応答候補が出力可能な対話システムでは， ほとんどの場合 , 各応答候補にシステムがスコアを付与 し，光のスコアに基づき応答を順位付けする．弚こで本 研究ではこの順位, もしくはスコアを対話破綻検出の適 用により変更することで, 応答候補のリランキングを行 い, 性能の変化を分析する.

本研究では, 分析のため以下の 3 種類の非タスク指向 型対話システムを用いた .

用例ベース対話システム (IRS) 用例ベースの対話シス テムとして，DBDC で使用された IRS システムを 用いる . IRS システムは IR-STATUS[Ritter 11] に準 拠した用例ベースの対話システムであり，入力され たユーザ発話と類似した用例を検索し，ヒットした 用例に対する応答をシステムの応答として使用する． 使用した用例は筆者らが収集した杂隹談対話データか ら抽出した . 本データは, 初対面の 2 名による 1 回 30 分のテキストチャットにより収集されたものであ る.IRS では 408 回分の対話から抽出した合計 26972 個の用例を使用している . 用例の検索には Apache Luceneを,形態素解析器には Kuromoji を用いた。光 の他のパラメータ・設定については Apache Lucene のデフォルト值を用いた .

応答候補は類似度の上位 10 件とし, 応答のスコ アには, Apache Lucene が出力した類似度を用いる 。

Neural Conversational Model (NCM) 本システムは,エ ンコーダ・デコーダモデルのニューラルネットワーク を用いた対話システムである。実装には KyotoNMT [Cromieres 16] を使用し，エンコーダには各 1000 次 元の LSTM を 4 層 , デコーダには各 1000 次元の LSTM を 4 層のネットワークを用いた . 語彙数は入 力, 出力ともに 80000 とし, Dropout 率は $20 \%$,パラ メータの最適化手法には Adam を用いた . 学習デー タには約 1000 万件の Twitter のツイート・リプライ ペアを使用した . 学習中のモデルの評価は学習デー タとは別の 1 万件のツイート・リプライペアにより 計算した BLEUを用いて行った。

応答候補は, 初期パラメータを変更して個別に学

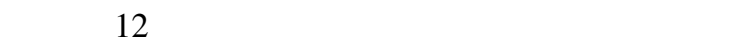

いる .ニューラル対話モデルでは，ビームサーチに より 1 つのモデルから複数の応答候補を得ることも 可能である [Vinyals 15]が，今回の実装・設定では， 句点の有無や末尾の違い (例: $\ulcorner$ です。」と「〜です よ。」) のような，ほぼ同一の応答候補が複数出力さ れたことから，このような設定で実験を行った，応 答のスコアには各応答の生成確率を単語数で正規化 した值を用いる．また，後述する対話データ (対話破 綻検出学習データ)の作成時には，応答時間の問題 から，12 個のモデルのうち BLEU が最も高かった 1 モデルを用いて対話を行った .

Neural Utterance Ranking モデル (NUR) Neural Utterance Ranking モデル (NUR モデル) は, 著者らが提 案したニューラルネットワークベースの対話モデル [Inaba 16]であり, 自動生成した複数の発話候補を 適切な順にランキングし, 高順位の発話を用いて対 話を行うモデルである . 学習設定・使用データは文 献 [Inaba 16]における実験で使用したものと同一で ある . 応答のスコアは NUR モデルが発話候補の順 位付けのために出力するスコアを用いる .

\section{4. 対話破綻検出}

本研究における対話破綻検出は, 対話破綻検出チャレ ンジ (DBDC) に準拠する.DBDC は人と対話システムに よる 2 者間テキスト対話 , および各システム発話に対す るアノテーションが提供され, 参加者は谷のデータを用 いて未知の対話に対する破綻検出器を作成し, 弚の性能 を競うコンペティションである.初回の DBDC [東中 15] では対話システムは 1 種類のみであったが, 2 回目以降 (DBDC2 [東中 16], DBDC3 [Higashinaka 17]) は複数の 種類のシステムによる対話データが用いられた .

アノテーションに関しては, 各システム発話に以下の 3 種類の破綻ラベルが付与されている .

O: 破綻ではない 当該システム発話のあと対話を問題な く継続できる。

T: 破綻と言い切れないが, 違和感を感じる発話 当該シ ステム発話のあと対話をスムーズに継続することが 困難 .

$\mathrm{X}$ : あきらかにおかしいと思う発話. 破綻 当該システム 発話のあと対話を継続することが困難

アノテーションは 1 発話に対し複数人で行われており， 破綻検出器は各発話についてアノテータ間の多数決によっ て決定されたラベル，およびラベルごとのアノテータの 分布を推定する。

\section{$4 \cdot 1$ 対話破綻検出手法}

現在最も性能の高い破綻検出手法はDBDC3 における Sugiyama の手法 [Sugiyama 17] であるが , この手法は非 公開のアノテーション付きコーパスに基づく素性を用い 
ており，再現が困難である。乥こで本実験では，光れに 次ぐ対話破綻検出手法として，DBDC2 で性能が最も高 かった杉山の手法 [杉山 16]を用いる.本手法は , システ ムによる急激な話題転換や対話行為の不自然なつながり など，対話システムに典型的な誤りのパターンを捉えた 素性を用い，Extra Trees Regressor[Geurts 06] で破綻ラ ベルの確率分布 $(p(O), p(T), p(X))$ を推定する手法であ る.なお，文献 [杉山 16] では対話行為アノテーション 済みのコーパスを用いて対話行為推定器を構築し，关の 結果を素性の 1 つとして使用しているが, 当該コーパス は非公開である. 乥こで本研究では新たに対話行為アノ テーション济みのコーパスを作成し, 対話行為推定器を 構筑した . 使用した対話行為クラスは 39 個であり，目黑 らが定義した対話行為 [目黑 12] をもとに決定した . 単 語 1〜3gram を素性とした多クラス SVM をコーパスに 含まれる 25555 発話で学習することにより，対話行為推 定器を学習した.SVMのカーネルは線形カーネルを用い た。なお，DBDC2 のデータを用いて対話破綻検出を行 う予備実験を行った結果，DBDC2 の結果とほぼ同等の 結果が得られることを確認した . 兴の際, 学習データと して全ての対話システムのデータを用いた場合と，シス テムごとにデータを分け，破綻検出先のシステムと同じ システムのデータのみを用いて学習を行う場合とで比較 を行った . 产の結果, 学習データは全て用いるのではな く, 対話システム別に用いたほうが性能が高いことが確 認された．乥こで, 本研究で用いる破綻検出の学習デー タはシステムごとに分け, 適用するシステムに応じて使 い分けることとした。

\section{$4 \cdot 2$ 対話破綻検出学習データ}

前節で述べた対話破綻検出手法の学習データとして， 3 章で述べた 3 種類の対話システムの対話破綻アノテー ション付き対話データを用いる . NCM と NUR システム のデータは対話のルール, アノテーション基準などの形 式をDBDCに準拠し，独自に収集したものであり，IRS データはDBDC2 で配布されているデータを谷のまま用 いる。

データには, 各対話システムとユーザとの 2 者間テキ ストチャット, および各システム発話に複数名のアノテー タが付与した対話破綻アノテーションが収録されている 各データの統計情報を表 1 に示す . 表の T ラベルの割合 とXラベルの割合より，IRS，NCM，NUR の順で破綻を 引き起こす応答を多く行う傾向があることが確認できる．

\section{5. 対話破綻検出適用実験}

本実験では, 対話システムが出力した応答候補リスト に対し，対話破綻検出を適用することでリランキングし， 光の結果を評価する。

*1 T を X とみなした場合
表 1 対話破綻検出学習データ

\begin{tabular}{|c|c|c|c|}
\hline & IRS & $\mathrm{NCM}$ & NUR \\
\hline 対話数 & 100 & 100 & 120 \\
\hline ユーザ発話数 & 1000 & 1000 & 1200 \\
\hline システム発話数 & 1100 & 1100 & 1320 \\
\hline アノテータ数 & 30 & 30 & 34 \\
\hline O ラベルの割合 & $31.1 \%$ & $47.4 \%$ & $57.7 \%$ \\
\hline T ラベルの割合 & $26.7 \%$ & $32.7 \%$ & $27.0 \%$ \\
\hline X ラベルの割合 & $42.1 \%$ & $17.2 \%$ & $15.2 \%$ \\
\hline Fleiss' $\kappa$ & 0.29 & 0.29 & 0.26 \\
\hline Fleiss' $\kappa(T+X){ }^{*}$ & 0.38 & 0.43 & 0.42 \\
\hline
\end{tabular}

* T を X とみなした場合

表 2 評価用データ

\begin{tabular}{l|c|c|c} 
& IRS & NCM & NUR \\
\hline \hline データ数 & 300 & 300 & 300 \\
\hline 文脈に含まれる発話数 & 1.37 & 2.14 & 2.04 \\
\hline 応答候補数 & 11.42 & 10.57 & 10.94 \\
\hline 応答候補の単語数 & 18.13 & 9.54 & 10.70 \\
\hline アノテータ数 & 4.61 & 5.92 & 3.88 \\
\hline アノ
\end{tabular}

対話破綻検出結果を適用した際の応答性能を評価する ためのデータとして，ユーザとシステムが交互に発話し た対話ログ (文脈) と文脈中の最後のユーザ発話に対する 複数の応答候補とスコア, および破綻ラベルが収録され たデータを用いる．データのフォーマットは文献 [Inaba 16]の実験で使用したデータと同一である . 対話システム は話者 2 名による対話ログを文脈として与えられ，文脈 中の最後の発話に対する応答候補を複数生成する．次に

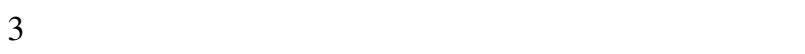
話破綻検出学習データと同樣の 3 種類の破綻ラベルを付 与することでデータを作成した .

応答性能の評価の際には, 文脈に対して発話が自然か 否かという点が重要であることから，アノテータの半分 以上が $\mathrm{O}$ と評価した応答を正例とし, 光れ以外の応答を 負例とする．今回の実験では，1 つの文脈に対する応答 候補の中に少なくとも 1 個以上の正例の応答が含まれて いるものを用いた

なお， NUR のデータについては , [Inaba 16] のデータ を光のまま用いる.IRS と NCM の文脈については [ Inaba 16]における実験て使用されたデータから取得した .弚の 際，システムにより10 個以上応答候補が生成できなかっ た文脈は除外した . 兴のため, 本実験のデータに含まれ る文脈はシステムにより異なる．本データの統計情報を 表 2 に示す . なお，IRS の文脈に含まれる発話数が他の 2 システムと比べ小さな値となっているのは, IRS の応 答性能の低さが原因で, 与えられた文脈が長い場合, 光 れに対する正例の応答が存在しなくなることが多くなっ たためである . 


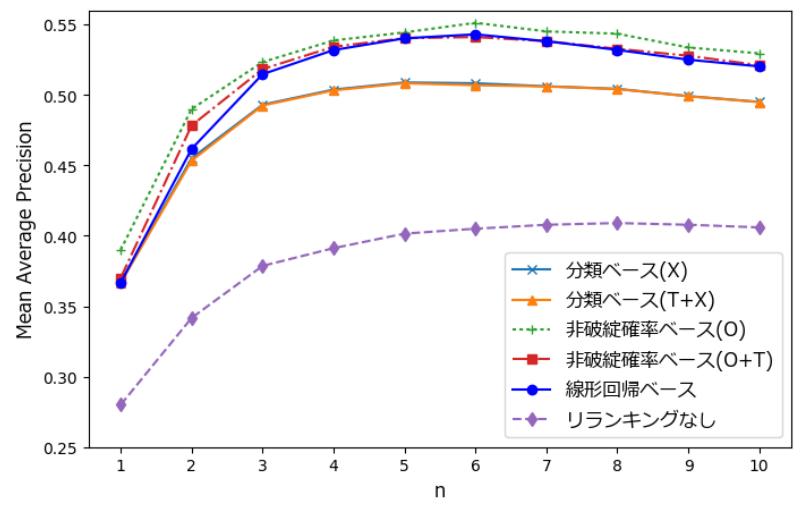

図 1 順位 $\mathrm{n}$ を変化させた際の MAP (IRS)

\section{1 適用手 法}

対話破綻検出手法をどのように適用すれば破綻を回避 し，応答性能を向上することができるかについては自明 ではない，光こで本研究では対話システムの応答候補に 対し，対話破綻検出手法を適用するための手法として，以 下の 3 つの手法を提案する .

分類ベース 破綻検出手法の出力した分類結果を重視し， 破綻と分類された応答候補を下位にする手法である． 破綻検出手法が出力した各ラベルの確率分布から， 最大確率となったラベルを分類結果とする . 本手法 では，Xのみを破綻とする場合 $(\mathrm{X})$ と，TとXの両 方を破綻とする場合 $(\mathrm{T}+\mathrm{X})$ の 2 つ設定で実験を行 う．T と Xの両方を破綻とする場合については，T と分類された応答候補のほうがX とされたものより も上位になるようリランキングする . 同一ラベル中 の順位は応答候補のスコアの順とする .

非破綻確率ベース 応答候補のスコアと，破綻検出手法 の出力した非破綻確率の積を新たなスコアとしてリ ランキングする．破綻検出手法が出力した確率分布 の $(p(O), p(T), p(X))$ のうち,$p(O)$ を非破綻確率と する場合 $(\mathrm{O})$ と， $p(O)+p(T)$ を非破綻確率とする 場合 $(\mathrm{O}+\mathrm{T})$ の 2 つで実験を行う .

線形回帰ベース 破綻検出手法が出力した各ラベルの確 率 $(p(O), p(T), p(X))$ と応答スコア $s$ を入力とした 線形回帰モデルにより新たなスコア $s_{\text {new }}$ を算出し， リランキングを行う. 学習時の損失関数は正例の応 答候補の教師スコアを 1.0 , 負例を 0.0 とした際の $s_{\text {new }}$ との平均二乗誤差とした . 線形回帰べース手法 はこのようなパラメータの最適化を伴うため, 10 分 割交差検証により評価する .

\section{$5 \cdot 2$ 実 験 結 果}

対話破綻検出を適用することでリランキングされた応答 候補の評価のため, ランキングの上位にどれだけ正例の応 答候補が出現しているかを示す指標である Mean Average Precision (MAP) を用いた . MAP の計算に用いる順位 $n$

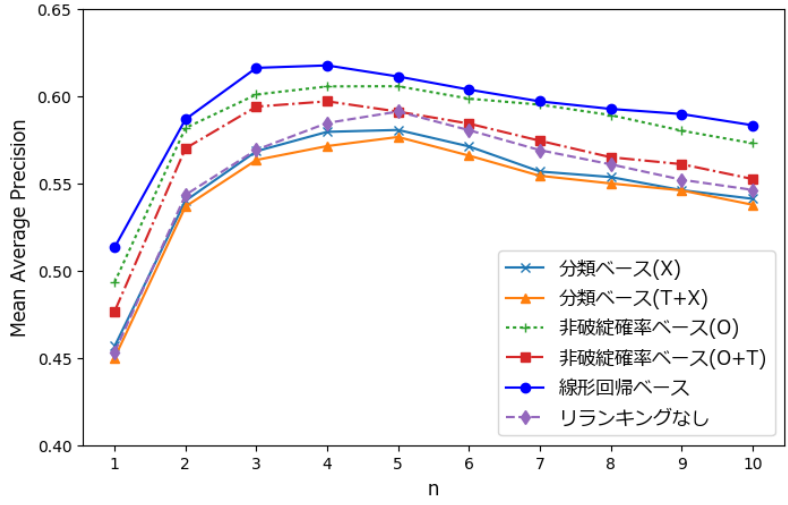

図 2 順位 $\mathrm{n}$ を変化させた際の MAP $(\mathrm{NCM})$

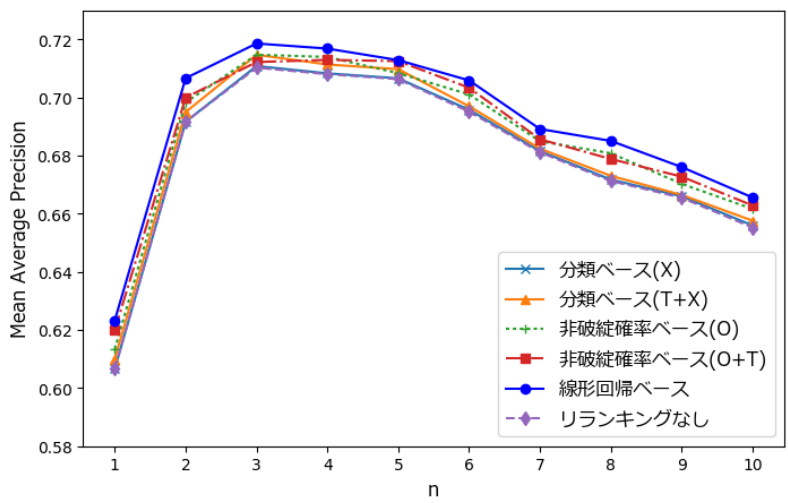

図 3 順位 $\mathrm{n}$ を変化させた際の MAP (NUR)

を上位 1 位〜10 位まで変化させた場合の IRS，NCM， NURの光れ光れの結果を図 1～図 3 に示した.結果より， 非破綻確率ベース $(\mathrm{O})$, 非破綻確率ベース $(\mathrm{O}+\mathrm{T})$, 線形 回帰ベースについては全てのシステムに対して性能向上 か確認できた .一方, 分類ベース $(\mathrm{X})$, 分類ベース $(\mathrm{T}+\mathrm{X})$ についてはシステムによって有効か否かが異なる結果と なった，個別に見ていくと IRS(図 1)では, 非破綻確率 ベース $(\mathrm{O})$ が最も大きく性能が向上し, 次いで非破綻確 率ベース $(\mathrm{O}+\mathrm{T})$ ，線形回帰ベースという順であった . 分 類べース $(\mathrm{X})$ と分類ベース $(\mathrm{T}+\mathrm{X})$ はほぼ同じ結果となり， 他の手法と比へ性能向上の幅は小さかったが, 弚れでも なおリランキングを行わない場合よりも大きく性能が向 上した . NCM(図 2) では, 線形回帰ベース, 非破綻確率 ベース $(\mathrm{O})$, 非破綻確率ベース $(\mathrm{O}+\mathrm{T})$ の順て性能向上の 幅が大きくなり, 分類ベース $(\mathrm{X})$ と分類べース $(\mathrm{T}+\mathrm{X})$ に 関してはリランキングを行わない場合よりも性能が悪化 する結果となった . NUR(図 3) では, 線形回帰ベースが 他の手法と比へ性能向上の幅が大きかったが , いずれの 手法も IRS と NCM に破綻検出手法を適用した場合より も，性能向上の幅は小さくなった .

分類ベースを適用した結果がシステムごとに大きく異 なっていたのは，破綻ラベルに基づく分類は人が行って も他者と一致させることが難しいタスクであったことが 
表 3 破綻検出手法の出力ラベルの分布 (括弧内は件数)

\begin{tabular}{l|c|c|c} 
& $\mathrm{O}$ & $\mathrm{T}$ & $\mathrm{X}$ \\
\hline \hline IRS & $20.7 \%(711)$ & $0.3 \%(10)$ & $79.0 \%(2706)$ \\
\hline NCM & $84.9 \%(2862)$ & $9.4 \%(317)$ & $5.7 \%(193)$ \\
\hline NUR & $96.6 \%(3173)$ & $2.1 \%(69)$ & $1.3 \%(42)$ \\
\hline
\end{tabular}

理由の 1 つと考えられる .これは, 表 1 に示した $\kappa$ 値が 低いことからも読み取ることができる．また実際に，本 研究で用いた破綻検出手法における 3 ラベルの分類正解 率 (accuracy) は 0.6 程度 [杉山 16] であり，十分であると は言えない性能であった . 一方で, 確率分布を用いる非 破綻確率ベースと線形回帰ベースについては 1 ラベルに 決定する場合と比較して, アノテーションのばらつきも 考慮できる手法であったため, 性能向上に有効であった と考えられる .

\section{$5 \cdot 3$ 考察}

$\S 1$ 対話破綻検出手法の出カラベルの分析

前節の結果より，対話破綻検出を適用することにより 応答性能の向上が可能であることが確認できたが, シス テムによって有効な適用手法や性能向上の度合いが異なっ ていた .この原因を調査するため, 対話破綻検出手法の 出力結果について分析を行った.

表 3 は，応答性能評価データに対し対話破綻検出手法 を適用した結果, 最大確率となったラベルの分布をシス テム別に示したものである .ここから , IRS ではX ラベ ルとなった応答候補が他と比べて非常に多いことがわか る.したがって, IRS の場合, より多くの応答候補のス コアが破綻検出手法により変更されることになり，性能 向上の幅が大きくなったといえる．一方，NCM と NUR では多くが $\mathrm{O}$ ラベルと判定されており，性能向上の余地 が小さかった結果，性能向上の幅も小さくなった . 特に， NUR では 96.6\%が O ラベルであり， T と X ラベルのみ を用いる分類ベースの手法は有効でないことがわかる .こ のように, 性能の高い対話システムにおいては, 破綻を 引き起こす応答が少ないことから，分類ベースの手法は 有効ではなく，O ラベルの情報も用いる非破綻確率ベー ス，線形回帰ベースの手法が有効であるといえる .

\section{$\S 2$ 対話破綻検出性能と応答性能}

前節でも見たように, 破綻検出性能とリランキング後 のシステムの応答性能向上の度合いは大きく関係してい ると思われる．乥こで，破綻検出性能が低い場合の応答 性能を調査するため, 破綻検出手法の学習データサイズ を小さくした場合の性能を調査した . 学習データ数を 10 刻みで変化させ , リランキング後の 1 位の発話のみを考 慮した MAPの結果を図 4 に示す.適用手法には非破綻確 率ベース $(\mathrm{O})$ を用いた . 図より, データ数の増加に応じ て MAPが向上していることが確認できる (NUR もわず かであるか性能が向上している). したがって, 対話シス

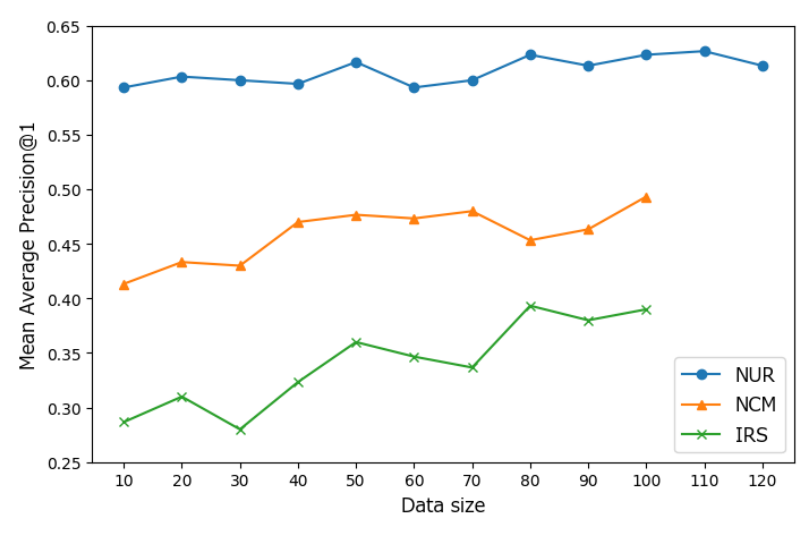

図 4 学習データ数と MAP

表 4 対話破綻検出適用前後の単語数と語彙数の変化

\begin{tabular}{c|c|c|c|c} 
& $\begin{array}{c}\text { 単語数 } \\
\text { (適用前) }\end{array}$ & $\begin{array}{c}\text { 単語数 } \\
\text { (適用後) }\end{array}$ & $\begin{array}{c}\text { 語彙数 } \\
\text { (適用前) }\end{array}$ & $\begin{array}{c}\text { 語彙数 } \\
\text { (適用後) }\end{array}$ \\
\hline \hline IRS & 18964 & 12276 & 1219 & 761 \\
\hline NCM & 11143 & 9317 & 363 & 332 \\
\hline NUR & 10659 & 10494 & 885 & 881 \\
\hline
\end{tabular}

テムに対して対話破綻検出を適用する場合には，対話破 綻検出性能を高めることが重要であることが確認できた . $\S 3$ 適用前後の応答の変化

対話破綻検出を適用した場合の応答の変化を分析する ため，適用した場合としない場合における，順位が 1 位 の応答に含まれる単語数と語彙数を調査した . リランキ ング手法には線形回帰ベースを用いた . 結果を表 4 に示 す.表より, 全てのシステムにおいて破綻検出手法の適 用により，単語数と語彙数の両方が小さくなる傾向があ ることがわかる．特に，IRS はど変化量が大きい，

表 5〜表 7 に対話破綻検出適用前後の応答の変化の例 を示した．リランキング手法には線形回帰ベースを用い た．表より，特に IRS では適用前と比べ適用後の応答は 短く簡潔なものとなっていることがわかる．このような 応答を行えば，対話破綻は減らすことが可能であるが， システム側からは何の情報も提供しない退屈な対話とな る危険性がある．応答候補の中に簡潔な応答が含まれる システムに対し対話破綻検出を適用する場合には，光の ような応答ばかりが選ばれないよう注意する必要がある といえる．また，NCM に関しても同樣の傾向が見られ る，一方，NURに関しては光ういった傾向はほとんど見 られなかった .これはNUR の応答候補の中に，簡潔な 応答が含まれることが少なかったためである．

\section{6. 対 話 実 験}

前章までの実験と分析により，対話破綻検出の適用は 対話破綻が発生する割合を減らす一方で，短く簡潔な応 答を増加させることが確認された . 本章ではユーザとシ 
表 5 対話破綻検出適用前後の応答の変化 (IRS)

\begin{tabular}{|c|c|c|}
\hline 文脈 & 対話破綻検出適用前 & 対話破綻検出適用後 \\
\hline A: ロシアンコーラうますぎィ! & $\begin{array}{l}\text { バイオリン！８年やって今弾けないっ } \\
\text { てもったいないですね。再開はしない } \\
\text { んですか? }\end{array}$ & うまいね \\
\hline $\begin{array}{l}\text { A: 明日カードリーダーとファイル買いた } \\
\text { いんだけどめんどい }\end{array}$ & $\begin{array}{l}\text { 弚うなってるといいですね〜。精進し } \\
\text { ます。 }\end{array}$ & 私もです。 \\
\hline $\begin{array}{l}\text { A: ダメだ今はタイミングが悪い } \\
\text { B: 大丈夫 ? } \\
\text { A: だめ }\end{array}$ & $\begin{array}{l}\text { そこまでしっかりと育てられるとは思 } \\
\text { いません。 }\end{array}$ & $\begin{array}{l}\text { いいですよ。光れに、だめじゃ } \\
\text { ないですよ。 }\end{array}$ \\
\hline
\end{tabular}

表 6 対話破綻検出適 (NCM)

\begin{tabular}{l|l|l} 
文脈 & 対話破綻検出適用前 & 対話破綻検出適用後 \\
\hline \hline $\mathrm{A}:$ 課題やってないけど授業に来た & そうなんだよね。お金がないんだよね。 & そうなんですか? \\
\hline $\mathrm{A}:$ 研究室に枕持ってこよ & 研究室に持ってきてないんですか? & 枕にしてください! \\
\hline $\mathrm{A}:$ 最近睡眠時間増えてやばい & 蒲田から近いんだっけ? & そうなんですか \\
$\mathrm{B}:$ 羡ましいよ〜 & & \\
$\mathrm{A}:$ 幽霊が出てくる夢を見るのだが & & \\
\hline
\end{tabular}

表 7 対話破綻検出適 (NUR)

\begin{tabular}{|c|c|c|}
\hline 文脈 & 対話破綻検出適用前 & 対話破綻検出適用後 \\
\hline $\begin{array}{l}\mathrm{A}: \text { 今日できることは明日でもできるっ } \\
\text { でう言ってこころを落ち着かせよう！ }\end{array}$ & こころと体は別だよね & こここのゆとりが欲しいかも \\
\hline 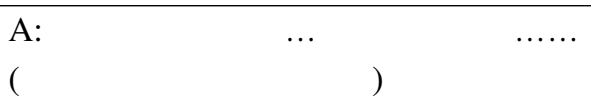 & $\begin{array}{l}\text { レッドブルとか眠眠打破とかきかない } \\
\text { んだよね }\end{array}$ & $\begin{array}{l}\text { エナジードリンクはレッドブル } \\
\text { がー番だね }\end{array}$ \\
\hline $\begin{array}{l}\text { A: 最近のレクサスの CMおもしろい! } \\
\text { B: レクサスお顔好きくないんよね } \\
\text { A: じゃあマツダはどう? }\end{array}$ & $\begin{array}{l}\text { レクサスは、楽しいクルマとは勾論言 } \\
\text { えない }\end{array}$ & $\begin{array}{l}\text { マツダのスポーツコンセプトす } \\
\text { ごく楽しみだよ }\end{array}$ \\
\hline
\end{tabular}

ステムが対話する実験を行い，破綻検出の適用による応 答の変化が , 対話後のユーザの印象にどのような影響を 及ぼすのかについて分析を行った .

\section{1 実 験 設 定}

対話システムは破綻検出手法の適用前後で最も応答内 容と性能の変化が大きかった IRS を用い, 適用手法には IRS に対し最も性能向上効果の高かった非破綻確率べー ス $(\mathrm{O})$ を用いた . 対話の形式・ルールは DBDC に準拠し て実験を行った . 対話はシステムの発話から開始し，ユー ザと交互に発話を行う.ユーザが 10 回目の応答を行い， 关れに対してシステムが 11 発話目を行った時点で対話 は終了となる . 対話は Web 上の専用サイトで行った .

本実験では，被験者はまず対話破綻検出ありと対話破 綻検出なしの両方のシステムと光れ光れ対話を行い，光 の後 , アンケートに回答する . どちらのシステムと先に 対話するかは被験者ごとにランダムとした . アンケート

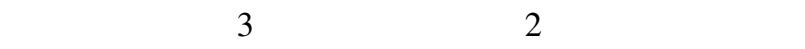
ちらかを 2 択で回答させた 。

・より自然な対話が行えたのはどちらか (自然さ)
表 8 対話実験結果 (括弧内は人数)

対話破綻検出あり $\mid$ 対話破綻検出なし

\begin{tabular}{c||c|c}
\hline \hline 自然さ & $\mathbf{5 9 . 1 \% ( 6 5 )}$ & $40.9 \%(45)$ \\
\hline 楽しさ & $46.1 \%(51)$ & $\mathbf{5 3 . 6 \% ( 5 9 )}$ \\
\hline 総合 & $\mathbf{5 5 . 5 \% ( 6 1 )}$ & $44.5 \%(49)$ \\
\hline
\end{tabular}

・より楽しい対話が行えたのはどちらか (楽しさ)

・総合的に見て良い対話システムはどちらか (総合) 被験者はクラウドソーシングサイト CrowdWorks*4で募 集した . 適切に対話が行われたことを確認するため，被 験者にはアンケートに加え, 対話ログも提出させること とした。

\section{$6 \cdot 2$ 実 験 結 果}

CrowdWorks で被験者を募集した結果，110 名による 対話データ, およびアンケート結果が得られた . 表 8 に アンケートの結果を示す．

表より，自然さに関しては破綻検出ありのシステムが， 
楽しさに関しては破綻検出なしのシステムが多いという 結果となった .これは破綻検出の適用により短く簡潔な 応答か増えることで対話破綻が回避された一方，応答の 多樣性が小さくなった結果であると考えられ，前章の実 験結果とも一致する．また，総合では破綻検出ありのシ ステムの方が良いシステムであると評価された .この結 果は, 対話システムに求められるのは自然さであり，汎用 的な応答が増加しても対話システムの利用満足度は向上 することを示唆している.前章の実験結果より，程度の差 はあるものの対話破綻検出の適用によりシステムの応答 の自然さは向上したことから，多くのシステムにとって 対話破綻検出手法を適用することは, システムの利用満 足度の向上に有効であることが示唆された .ただし , ア ンケートの各項目について有意水準 5\%でカイ二乗検定 を実施したところ，いずれの項目についても有意差は確 認できなかった .

実際の破綻検出を適用した対話システムの対話例と， 各応答において破綻検出を適用していないシステムの応 答を表 9 に示した .この対話例からも，対話破綻検出を 適用することで応答の自然さは向上している一方で, 発 話は短く，汎用的なものが多くなっていることがわかる .

\section{7. おわりに}

本研究では 3 種類の対話システムの応答に対し, 対話 破綻検出手法を適用することで，応答性能を向上できる かを実験的に評価した . 対話破綻検出の適用手法として， 破綻ラベルの分類結果を用いる分類ベース手法，破綻で はない確率を用いる非破綻確率べース手法, 各ラベルの 確率分布と応答スコアを線形回帰モデルの入力として用 いる線形回帰べースの3つを提案した . 実験の結果 , 非 破綻確率ベース手法と線形回帰ベース手法については全 てのシステムの応答性能の向上が確認できた . 一方 , 分 類ベース手法に関してはシステムの応答性能を悪化させ るケースが確認された．また，対話破綻検出を適用する ことにより短く簡潔な応答か増加することも確認された . さらに, 対話破綻検出の適用の有無による性能の比較の ため, 破綻検出を適用した対話システムと被験者か㳔話 する実験を実施した，弚の結果，対話破綻検出の適用に より対話の自然さは向上し, 楽しさは低下することが確 認された ,ただし, 総合的には適用したシステムのほうが 優れたシステムであると評価されたことから，提案した 対話破綻検出の適用手法は有効であることが示唆された .

今後の課題は，対話破䋎検出を適用した際に簡潔な応 答が増加する問題への対処である，光のために，破綻検 出結果だけではなく，応答の内容を考慮可能な破綻検出 結果の適用手法を検討していく予定である.

\section{$\diamond$ 参 考 文 献 $\diamond$}

[Charras 16] Charras, F., Duplessis, G. D., Letard, V., Ligozat, A.L., and Rosset, S.: Comparing system-response retrieval models for open-domain and casual conversational agent, in Second Workshop on Chatbots and Conversational Agent Technologies (WOCHAT) (2016)

[Cromieres 16] Cromieres, F.: Kyoto-NMT: A Neural Machine Translation implementation in Chainer, in Proceedings of COLING 2016: System Demonstrations, pp. 307-311 (2016)

[Curry 16] Curry, A. C. and Rieser, V.: A Subjective Evaluation of Chatbot Engines, in Second Workshop on Chatbots and Conversational Agent Technologies (WOCHAT) (2016)

[Geurts 06] Geurts, P., Ernst, D., and Wehenkel, L.: Extremely randomized trees, Machine Learning, Vol. 63, No. 1, pp. 3-42 (2006)

[Higashinaka 17] Higashinaka, R., Funakoshi, K., Inaba, M., Tsunomori, Y., Takahashi, T., and Kaji, N.: Overview of Dialogue Breakdown Detection Challenge 3, in Proceedings of Dialog System Technology Challenge 6 (DSTC6) Workshop (2017)

[Inaba 16] Inaba, M. and Takahashi, K.: Neural utterance ranking model for conversational dialogue systems, in Proceedings of 17th Annual Meeting of the Special Interest Group on Discourse and Dialogue (SIGDIAL2016), pp. 393-403 (2016)

[Mori 16] Mori, H. and Araki, M.: Selection method of an appropriate response in chat-oriented dialogue systems, in Proceedings of 17th Annual Meeting of the Special Interest Group on Discourse and Dialogue (SIGDIAL2016), pp. 228-231 (2016)

[Ritter 11] Ritter, A., Cherry, C., and Dolan, W. B.: Data-driven response generation in social media, in Proceedings of the Conference on Empirical Methods in Natural Language Processing (EMNLP2011), pp. 583-593 (2011)

[Sugiyama 16] Sugiyama, H.: Utterance selection based on sentence similarities and dialogue breakdown detection on NTCIR-12 STCV task, in Proceedings of the 12th NTCIR Conference on Evaluation of Information Access Technologies, pp. 552-553 (2016)

[Sugiyama 17] Sugiyama, H.: Dialogue breakdown detection based on estimating appropriateness of topic transition, in Dialog System Technology Challenges (DSTC6) (2017)

[Vinyals 15] Vinyals, O. and Le, Q.: A neural conversational model, in Proceedings of the ICML Deep Learning Workshop, pp. 1-7 (2015)

[Wallace 08] Wallace, R.: The anatomy of A.L.I.C.E., Parsing the Turing Test, pp. 181-210 (2008)

[Weizenbaum 66] Weizenbaum, J.: ELIZA-a computer program for the study of natural language communication between man and machine, Communications of the ACM, Vol. 9, No. 1, pp. 36-45 (1966)

[杉山 16] 杉山 弘晃 : 発話生成における誤りパターンの分析に基 づく対話破綻検出, 第 78 回言語・音声理解と対話処理研究会 (第 7 回対話システムシンポジウム), 人工知能学会研究会資料 SIG-SLUD-B505-23, pp. 81-84 (2016)

[東中 15] 東中 竜一郎, 船越 孝太郎, 小林 優佳, 稲葉 通将 : 対話 破綻検出チャレンジ, 第 75 回言語・音声理解と対話処理研究会 (第 6 回対話システムシンポジウム), 人工知能学会研究会資料 SIG-SLUD-75-B502, pp. 27-32 (2015)

[東中 16] 東中竜一郎, 船越 孝太郎, 稲葉 通将, 荒瀬由紀, 角森 唯 子: 対話破綻検出チャレンジ 2 , 第 78 回言語・音声理解と対話 処理研究会 (第 7 回対話システムシンポジウム), 人工知能学会 研究会資料 SIG-SLUD-B5025-19, pp. 64-69 (2016)

[目黑 12] 目黑豊美, 東中竜一郎, 堂坂 浩二, 南泰浩: 聞き役対話 の分析および分析に基づいた対話制御部の構築, 情報処理学会論 文誌, Vol. 53, No. 12, pp. 2787-2801 (2012)

〔担当委員 : 平 博 順〕

2018 年 6 月 22 日 受理 
表 9 対話破綻検出を適用した IRS との対話例と適用していない IRS の応答

\begin{tabular}{|c|c|c|}
\hline 話者 & 対話例 (対話破綻検出を適用した IRS) & IRS の応答 (対話破綻検出なし) \\
\hline システム & こんにちは。好きな食べ物は何ですか? & (対話破綻検出適用時と同じ) \\
\hline ユーザ & 寿司が好きです & \\
\hline システム & 今日はお昼にお寿司食べました & 結構食べるからおなか一杯になるよ。 \\
\hline ユーザ & いいですね、美味しかったですか？ & \\
\hline システム & はい。 & はい！これまた財布に優しかったですよ。 \\
\hline ユーザ & 私は今日のお昼はうどんを食べました & \\
\hline システム & まだ食べてない。 & 海鮮井を食べたよ。 \\
\hline ユーザ & あなたの好きな食べ物は何ですか? & \\
\hline システム & $\begin{array}{l}\text { 私もラーメンは好きです。先日、誘われて、天一 } \\
\text { のラーメンを食べに行ってきました。 }\end{array}$ & （対話破綻検出適用時と同じ） \\
\hline ユーザ & 天一のラーメンは美味しかったですか？ & \\
\hline システム & $\begin{array}{l}\text { ラーメンいいですよね。お腹減っている時に食べ } \\
\text { 物の話は禁物ですね。 }\end{array}$ & (対話破綻検出適用時と同じ) \\
\hline ユーザ & スポーツは何が好きですか？ & \\
\hline システム & $\begin{array}{l}\text { 最近は全然していませんが、基本的には好きです } \\
\text { よ。 }\end{array}$ & $\begin{array}{l}\text { 弚うですねえ、以前はサッカー部だったんで、光 } \\
\text { の時はがっつり運動してました。今も家の前の道 } \\
\text { でボール蹴ったりしますよ。 }\end{array}$ \\
\hline ユーザ & 私は毎週フットサルをやってるんですよ & \\
\hline システム & ありがとうございます！さっ光くやってみます。 & $\begin{array}{l}\text { 一人暮らしの友達がもう一人居て、光この家でも } \\
\text { 最近開かれるようになったので、週 } 2 \text { 回のときも } \\
\text { ありますよ! }\end{array}$ \\
\hline ユーザ & ワールドカップが始まりましたが見てますか？ & \\
\hline システム & $\begin{array}{l}\text { うーん、覚えてないです。今日明日からでしたつ } \\
\text { け? 注目の3 人が出ますよね。 }\end{array}$ & $\begin{array}{l}\text { 弚うだよね。テレビのない生活をしているのかと } \\
\text { 思いました。2０１１年ですよね、やっばり薄型 } \\
\text { がほしいですね。 }\end{array}$ \\
\hline ユーザ & 私は乾選手に注目してます & \\
\hline システム & スピードスケートの岡崎選手が大注目でしたね。 & (対話破綻検出適用時と同じ) \\
\hline ユーザ & スピードスケート好きなんですか？ & \\
\hline システム & 何が好きなのですか? & $\begin{array}{l}\text { 弚うですか! 私は苦手です。。冬服は重いし高 } \\
\text { い。。。 }\end{array}$ \\
\hline
\end{tabular}

著者紹介

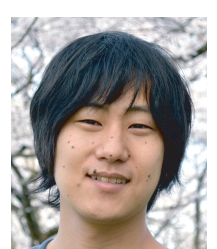

稲葉 通将(正会員)

2012 年名古屋大学大学院情報科学研究科博士後期課程修 了.同年，広島市立大学大学院情報科学研究科助教、現在 に至る.博士 (情報科学) . 対話システム, 対話処理に関す る研究に従事。電子情報通信学会, 情報処理学会, 言語処 理学会, ACL 各会員.

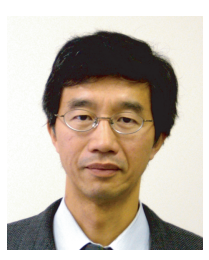

高橋 健一(正会員)

1977 年名古屋工業大学情報工学科卒業. 1979 年同大学院 工学研究科修士課程修了. 同年名古屋工業大学工学部助手 同大学講師，助教授を経て，1994 年広島市立大学情報科学 部教授。現在に至る。工学博士。主に機械学習,パターン 情報処理の研究に従事。電子情報通信学会, IEEE 各会員 